这 UNIVERSITY OF AMSTERDAM

\title{
THE IDEA OF “RULES” IN THE SOURCES OF INTERNATIONAL LAW
}

\author{
Jean d'Aspremont
}

Amsterdam Law School Legal Studies Research Paper No. 2014-51 Amsterdam Center for International Law No. 2014-28 


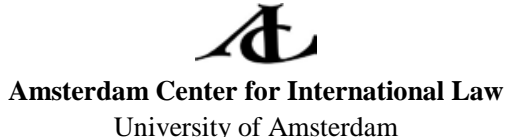

University of Amsterdam

\section{RESEARCH PAPER SERIES}

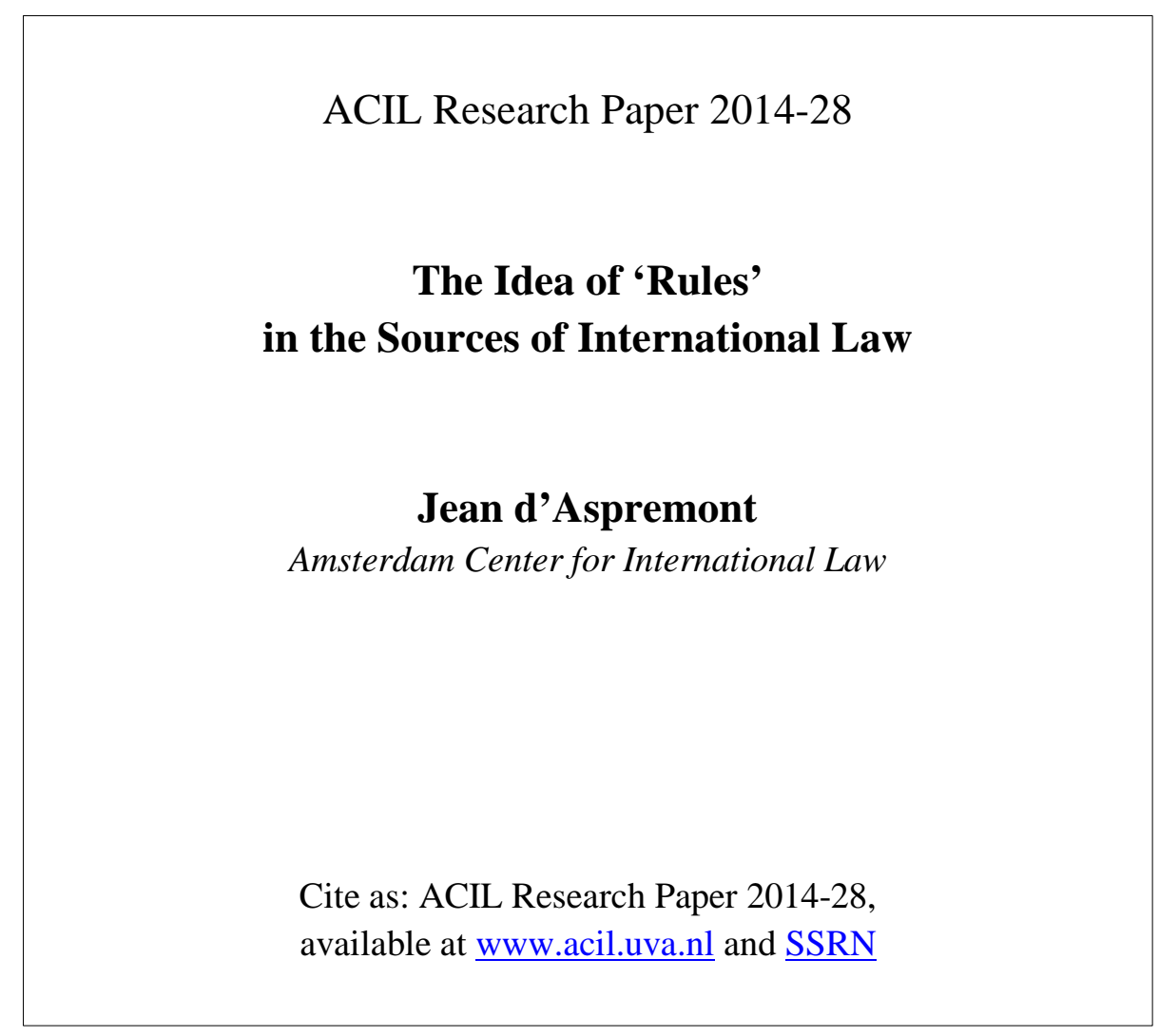

Forthcoming in: 84 British Yearbook of International Law (2014) 


\title{
THE IDEA OF ‘RULES’ IN THE SOURCES OF INTERNATIONAL LAW
}

\author{
By Jean d'Aspremont ${ }^{1}$
}

This article argues that the dominant narrative according to which the sources of international law constitute a set of rules for the identification of other legal rules is a comforting parable that has eroded international lawyers' critical attitude, contributing to the general disrepute of the sources of international law. The sources of international law are better understood as a set of communitarian constraints irreducible to rules. By vindicating a conception of the sources of international law construed not as a set of rules but as a set of communitarian constraints, this article promotes, elucidates and refines a social theory of sources of international law ${ }^{2}$ and addresses some of the conceptual questions that it raises. ${ }^{3}$

I start by exploring the various manifestations, in international legal scholarship and practice, of the idea that the sources of international law constitute a set of rules. This is what is called here the 'first order ruleness' of the sources of international law (I). The article goes on to spell out the normative choices against the backdrop of which it ventures into an unravelling of the ruleness of the sources of international law and, especially, the concept of social foundations of the sources of international law (II). It then recalls that the social practice generative of sources cannot be apprehended objectively, that

\footnotetext{
${ }^{1}$ Professor of Public International Law, University of Manchester and Professor of International Legal Theory, University of Amsterdam.http://www.ssrn.com/author=736816 The author wishes to thank Michael Giudice, Sahib Singh, Richard Collins, Anne van Mulligen and Alexia Solomou as well as the anonymous reviewers for their comments on an earlier version. The usual disclaimers apply.

${ }^{2}$ See J d'Aspremont, Formalism and the Theory of Sources of International Law (OUP 2011). See also J d'Aspremont 'Towards a New Theory of Sources in International Law' in A Orford and F Hofmann (eds), Oxford Handbook on the Theory of International Law (OUP 2015 forthcoming).

${ }^{3}$ S Singh, 'International Law as a Technical Discipline: Critical Perspectives on the Narrative Structure of a Theory' in J. d'Aspremont, Formalism and the Sources of International Law: A Theory of the Ascertainment of Legal Rules (paperback edition OUP 2013) 236-261, Appendix 1 and below, pp. xx-xx; T Meyer 'Towards a Communicative Theory of International Law' (2013) 13 Melbourne Journal of International Law 1; I Venzke, 'Post-Modern Perspectives on Orthodox Positivism' in J Kammerhofer and J d'Aspremont (eds), International Legal Positivism in a Post-modern World (CUP 2014 forthcoming); D Tan, 'Review of Formalism and Sources of International Law: A Theory of the Ascertainment of Legal Rules’ (2012) 31 University of Tasmania Law Review 167.
} 
is without simultaneously making a choice on a specific descriptive framework to define such practice. This is why international lawyers are often tempted to revert to a rule-based cognitive standpoint to apprehend the social foundations of the sources of international law, thereby allowing ruleness to return through the backdoor. This is what is called here the 'second order ruleness' of the sources of international law (III). With a view to resisting both first and second order ruleness, I argue that the social practice generative of the law-ascertainment criteria composing the sources of international law can be principled by virtue of communitarian constraints in the absence of any rule. This is what is called the 'rulelessness' of the sources of international law (IV). I conclude that rebelling against the comforting idea of rules in the sources of international law allows international lawyers to avoid what will be described in the following paragraphs as the pitfalls of infinite regress and circularity inherent in ruleness while simultaneously facilitating the possibility of communication that is required for legal argumentation to take place among professional international lawyers (V).

Before developing the argument against the first and second order ruleness of the sources of international law, three important caveats must be formulated. First, it must be stressed that moving away from the idea of rules in the sources of international law does not imply a rejection of the idea of rules in international law as a whole. The rejection of ruleness of the sources of international law is not meant as a resuscitation of the process-based and policy-oriented approach advocated by some scholars. ${ }^{4}$ The rulelessness promoted in this article is directed at the sources of international law and leaves intact a possible rule-based understanding of international law as a whole. ${ }^{5}$

\footnotetext{
${ }^{4}$ See e.g. M Reisman, 'International Law-Making: A Process of Communication’ (1981) 75 ASIL Proceedings 101; R Higgins, Problems and Process: International Law and How We Use It (OUP 1995) 8-10.

${ }^{5}$ For the sake of this article, it is modestly assumed that international law constitutes a heterogeneous phenomenon which can be cognised and constructed in many different ways, be it as a set of rules, a narrative, a set of argumentative practices and techniques, a mechanism to produce authoritative statements, etc. For a similar opinion, see J Crawford and M Koskenniemi, 'Introduction' in J Crawford and M Koskenniemi (eds), Cambridge Companion to International Law (CUP 2012) 2 ('International law can be recognised as law but is also a language of government, a bundle of techniques as well as a framework within which several constructivist projects are articulated'). It is true that the idea that international law as a whole boils down to a set of rules has often been considered the roots of many ailments. These criticisms, albeit somewhat overblown, rightly point out that rules can only apprehend one thin aspect of international law, for they come with limited descriptive virtues. Yet, this is not the question at stake here.
} 
Second, it is important to emphasise that a move from rules to communitarian constraints in the sources of international law does not necessarily involve a deformalisation of the law-identification criteria by virtue of which international rules are ascertained. The rulelessness vindicated here can accommodate formalism in the practice of lawidentification. In that sense, this article is premised on the idea that ruleness of the sources of international law does not necessarily have the monopoly on formalism. Formalism in the practice of lawidentification is conceivable in the absence of rules. This is however not a question to be explored here. ${ }^{6}$

Third, something should be said with respect to the relationship between ruleness and bindingness. For the purposes of the argument made here, ruleness and bindingness ought to be distinguished. The ruleness that is discussed here pertains to the format in which sources of international law - and thus the law-identification criteria recognised as valid - manifest themselves in practice. The ruleness does not bear upon the effect of law-identification, that is, the recognition that a certain standard of behavior belongs to the international legal order or one of its sub-orders and produces binding effects within that order. In that sense advocating that sources of international law do not constitute a set of rules but, rather, a set of communitarian constraints does not alter the fundamental function of the sources of international law, that is, to provide criteria for the identification of those (primary) rules that are binding in their legal order of membership. The bindingness of the (primary) rules of international law is thus not affected by the fact that such rules are identified by virtue of criteria generated by social practices rather than criteria enshrined in other rules. The foregoing is however without prejudice to the bindingness of the law-identification criteria found in the sources of international law themselves, as will be seen.

\section{THE COMFORTING PARABLE: FIRST ORDER RULENESS OF THE SOURCES OF INTERNATIONAL LAW}

I start with the idea that the sources of international law boil down to a set of rules on the ascertainment of other rules. The idea of rules in the sources of international law has proved extremely popular among international lawyers. In this Part, I illustrate that fact, and then look at some of the underlying reasons for it.

\footnotetext{
${ }^{6}$ This has been the object of discussion elsewhere. See J d'Aspremont, Formalism and the Sources of International Law (OUP 2011).
} 
One does not need to carry out extensive research to grasp the preponderance of a rule-based understanding of the sources of international law. General as well as specialised literature on sources of international law is dominated by the idea that sources of international law constitute a set of rules properly so-called.

The idea of ruleness of sources is particularly common in connection with customary international law. Among others, the International Law Association's 2000 London Statement of Principles Applicable to the Formation of (General) Customary International Law adopted a rule-based approach to rules. ${ }^{8}$ The same holds for the work of the International Law Commission's (ILC) Special Rapporteur on the identification of customary international law which, despite its selfrestraint, takes a similar rule-based conception of the sources of international law. ${ }^{9}$ The ruleness of sources, although it has not been

\footnotetext{
${ }^{7}$ On few examples can be provided here. J Brierly, 'The Basis of Obligation in International Law' in H Lauterpacht and CHM Waldock (eds) The Basis of Obligation in International Law and Other Papers by the Late James Leslie Brierly (Clarendon Press 1959) 1, 10; P Guggenheim, Traite de droit international public (Georg \& Cie 1953) 6-8; P Weil, 'Le droit international en quête de son identité - Cours général de droit international public' (1992) 237 Recueil des cours 131; A D’Amato, 'The Concept Of Special Custom In International Law' (1969) 63 AJIL 211; T Nardin, Law, Morality and the Relations of States (Princeton University Press 1983) 172 (arguing however that there is no rule on customary international law). It is noteworthy that Michael Wood uses quotation marks when he refers to the rules for the formation of customary international law: see M Wood, 'What Is Public International Law? The Need for Clarity about Sources' (2011) 1 Asian Journal of International Law 205, 213. Malcolm Shaw speaks about 'provisions operating with the legal system on a technical level': see M Shaw, International Law ( 5 th $^{\text {edn, CUP }}$ 2003) 66. Hugh Thirlway, for his part, speaks about the 'law of sources': see H Thirlway, The Sources of International Law (OUP 2014). The same idea of ruleness also imbues those commonly heard statements that article 38 is declaratory of general international law: See A Pellet, 'Article 38' in A Zimmermann, C Tomuschat, K Oellers-Frahm, C Tams (eds), The Statute Of the International Court of Justice. A Commentary (2nd edn, OUP 2012) 750; G Abi-Saab, 'Les sources du droit international: essai de deconstruction', in Liber Amicorum in Tribute to Professor Eduardo Jiménez de Aréchaga (Fundacici de Cultura Universitaria 1994) 29-49. The same holds with those works that attempt to transpose Hart's Concept of Law to sources of international law, and especially to theory of customary international law, see GJH Van Hoof, Rethinking the Sources of International Law (Kluwer Law 1983); GM Danilenko, Law-Making in the International Community (Martinus Nijhoff 1993) 16 et seq.; GM Danilenko, 'The Theory of International Customary International Law' (1998) 31 German YBIL 9-47; H Meijers, 'How is International Law Made?' (1979) 9 Netherlands YBIL 3.

${ }^{8}$ Final Report of the Committee on Formation of Customary (General) International Law, ILA London Conference (2000), para. 6.

${ }^{9}$ First Report on the Formation and evidence of customary international law by M Wood, 17 May 2013, A/CN.4/663, para. 38: 'It is perhaps unnecessary, at least at this stage, to enter upon the question of the nature of the rules governing the formation and identification of rules of customary international law, for example, whether such rules are themselves part of customary international law. But as in any legal system, there must in public international law be rules for identifying the sources of the law. These can be found for
} 
uncontested, ${ }^{10}$ equally dominates the theory of international treaties. With respect to conventional sources, this idea is probably the specific prolongation of the law of treaties being itself cast in the form of formal conventional rules. ${ }^{11}$

The reasons for the overall success of ruleness of the sources of international law are many. It suffices to mention a few of them here. A compelling explanation undoubtedly lies with ruleness being associated with another popular idea among international legal scholars, namely that international law is composed of both primary and secondary rules - that is the distinction between norms of conduct and systemic mechanisms. The distinction between primary and secondary rules inherited from British analytical jurisprudence - constitutes a dominant narrative in international legal scholarship as well as an ingrained paradigm which international legal scholars, legal advisers, counsel, judges and teachers constantly rely on and perpetuate. Even though international lawyers are well aware that the distinction is not conceptually watertight and often collapses, ${ }^{12}$ they continuously resort to $\mathrm{it}^{13}$ especially in connection with the sources of international law which they specifically portray as a set of secondary rules. According to this common understanding of the distinction between primary and secondary rules embraced by international lawyers, the sources of international law are said to constitute a specific type of secondary rules, namely a (family of) rule(s) of recognition. ${ }^{14}$ This association between

present purposes by examining in particular how States and courts set about the task of identifying the law'.

${ }^{10}$ It is noteworthy that some prominent members of the ILC expressed strong reservations as to the status of rules of the rules on interpretation: ILC, 726th Meeting, A/CN.4/167, reproduced in (1964-I) Ybk Int'l L Comm 20-1, para. 15 (Verdross).

${ }^{11}$ This approach was not followed for the international law of state responsibility. See $\mathrm{J}$ Crawford, S Olleson and J Peel, 'The ILC's Articles on Responsibility of States for Internationally Wrongful Acts: Completion of the Second Reading' (2001) 12 EJIL 963; J Crawford and S Olleson, 'The Continuing Debate on a UN Convention on State Responsibility’ (2005) 54 ICLQ 959.

${ }^{12}$ See N Bobbio, 'Nouvelles réflexions sur les normes primaires et secondaires' in N Bobbio, Essais de théorie droit (Bruylant/LGDJ 1998) 159ff. Austin and Ihering had already pointed out that the distinction collapses with respect to law-applying authorities for whom secondary rules function as primary obligations. It has always been argued that the dichotomy rests on the very unstable and ever-changing notion of internal point of view. See BZ Tamanaha, 'A Socio-Legal Methodology for the Internal/External Distinction: Jurisprudential Implications’ (2006) 75 Fordham Law Review 1255, 1264.

13 See the distance carefully advocated by A Nollkaemper and D Jacobs, 'Shared Responsibility in International Law: A Conceptual Framework’ (2013) 34 Michigan Journal of International Law 408-412.

${ }^{14}$ See N MacCormick, 'The Concept of Law and the Concept of Law' in RP George (ed.), The Autonomy of Law: Essays of Legal Positivism (OUP 1996) 163, 170-9. See also Joseph Raz's contention that a legal system may have more than one rule of recognition: J Raz, 'The Identity of Legal Systems’ (1971) 59 California Law Review 795, 806. 
the sources of international law and the concept of rule of recognition contributes to the general belief - and the corresponding narrative among international lawyers that the sources of international law boil down to a (set of) rule(s) properly so-called.

The appeal of the distinction between primary and secondary rules can be explained by virtue of its methodological, argumentative, and authority-enhancing benefits. ${ }^{15}$ Among them, the specific possibility it offers for believing that the 'normative' and the 'systemic' can be distinguished probably constitutes its paramount virtue. It is this potential that explains why it has been so extensively resorted to in both the theory and practice of international law. For instance, the distinction has allowed codification enterprises to be more realistically delineated as is illustrated by the well-known life-saving move made by the ILC in its work on the law of international responsibility. ${ }^{16}$ Likewise, the perceived possibility to distinguish the 'normative' from the 'systemic' has allowed international legal scholars to focus on the aesthetics of the system, while turning a blind eye to (the dirt of) the battle for the making of standards of conduct for international actors. In the same vein, the dichotomy has allowed judges to disguise normative problemavoidance strategies with apparent systemic sophistication. ${ }^{17}$ In teaching, the resort to this dichotomy allows the teacher to make international

\footnotetext{
${ }^{15}$ The success of that dichotomy probably also originates in the "tendency to try to confer upon international law some delimited time, space and subject matter for its "proper" (albeit not autonomous) operation'. See F Johns, Non-legality in International Law Unruly Law (CUP 2013) 8. On the descriptive limitations of the theory of secondary rules, see M Prost, The Concept of Unity in Public International Law (Hart 2012) 128.

${ }^{16}$ Roberto Ago is considered as the saviour of the codification of the law of international responsibility for having introduced the distinction between primary and secondary rules; see second Report of Roberto Ago, A/CN.4/233, 20 April 1970, (1970-II) Ybk Int'l L Comm 178-9, para. 7-11. On this distinction, see J Combacau et D Alland, 'Primary and Secondary Rules in the Law of State Responsibility: Categorizing International Obligations', (1985) Netherlands YBIL 82-109. See also E David, 'Primary and Secondary Rules in the Law of International Responsibility' in J Crawford, A Pellet and S Olleson (eds), The Law of International Responsibility (OUP 2010) 27, 29 ff. Crawford seems to have highlighted how functional the distinction was: 'the distinction between primary obligations and secondary rules of responsibility is to some extent a functional one, related to the development of international law rather than to any logical necessity'. See J Crawford, 'The ILC's Articles on Responsibility of States for Internationally Wrongful Acts: A Retrospect' (2002) 96 AJIL 874, 879, and see further J Crawford, State Responsibility: The General Part (CUP 2013) 64-66. For some critical remarks on the use of this distinction in the law of international responsibility, see $\mathrm{J}$ d'Aspremont, 'The Articles on the Responsibility of International Organizations: Magnifying the Fissures in the Law of International Responsibility' (2012) 9 International Organizations Law Review 15.

${ }^{17}$ See e.g. Jurisdictional Immunities of the State (Germany v. Italy: Greece intervening), ICJ Rep 2012, p. 99, paras. 58, 95, 100. On this aspect of the judgment, see S Talmon, 'Jus Cogens after Germany v. Italy: Substantive and Procedural Rules Distinguished’ (2012) 25 Leiden Journal of International Law 979.
} 
law a credible story by giving it an internal inductive dimension ${ }^{18}-$ and even a tinge of 'romanticism'.

But the success of the idea of rules in international legal scholarship and practice cannot be exclusively traced back to the popularity of the distinction between primary and secondary rules. Other reasons may be mentioned. One of them is of an epistemological kind. Indeed, in all its variants, the ruleness of the sources of international law is seen as comforting because it protects international lawyers from difficult - and frustrating - theoretical explorations. ${ }^{20}$ In particular it allows one to escape the necessity to investigate social phenomena behind lawidentification processes and to stick to a purely internal perspective. ${ }^{21}$ Ruleness makes it possible to think of the ultimate source of sources as strictly legal, thereby dispensing with any social inquiry about their foundations. ${ }^{22}$ All-in-all, the rule-based approach to sources allows international lawyers to tautologise the foundations of the international legal system and to eschew theoretical or sociological debates about foundational matters. ${ }^{23}$ In that sense, the ruleness of the sources of international law can be seen as one of the manifestations of the post-

\footnotetext{
${ }^{18}$ Florian Hoffman, 'Teaching General Public International Law', in J Kammerhofer and J d'Aspremont (eds), International Legal Positivism in a Post-Modern World (CUP 2014 forthcoming).

${ }^{19}$ See G Simpson, 'On the Magic Mountain: Teaching Public International Law’ (1999) 10 EJIL 70, 72.

${ }^{20} \mathrm{~T}$ Kuhn, The Structure of Scientific Revolutions (50th Anniversary Edition, University of Chicago Press 2012) 20: 'When the individual scientist can take a paradigm for granted, he need no longer, in its major works, attempt to build his field anew, starting from first principles and justifying the use of each concept introduced'.

${ }^{21}$ The quintessence of such an internal perspective is Kelsen. This is also what led authors embracing a Kelsenian understanding of law to argue that removing the question of the validity of a legal system by grounding law-ascertainment in social practice demotes legal science to legal sociology. Such a conception of law-ascertainment includes the study of 'Is' in the scope of a science which should only be concerned with the study of 'Ought'. See J Kammerhofer, Uncertainty in International Law: A Kelsenian Perspective (Routledge 2010) 227. For a similar criticism, see D Priel, 'Positivism and the Separation of Law and Jurisprudence', Research Paper No. 25-2011, Osgoode Hall Law School, 2. It is noteworthy that this charge has always been expressly conceded and even assumed by Hart himself. See HLA Hart, The Concept of Law (2nd edn, OUP 1994) v.

${ }^{22}$ For some critical thoughts, see S Besson, 'Theorizing the Sources of International Law', in S Besson and J Tasioulas (eds), The Philosophy of International Law (OUP 2010) 181. See in general jurisprudence A Marmor, Philosophy of Law (Princeton University Press 2011) 49.

${ }^{23}$ This was one of the reasons why Kelsen proposed to internalise the foundation of sources. For a discussion about the move from an internal to an external perspective, see A Watson, 'The Structure of Blackstone's Commentaries' (1988) 97 Yale Law Journal 795. For Anthony Sebok, Hart should be praised for working out the deficiencies of early positivist theories: A Sebok, 'Misunderstanding Positivism' (1995) 93 Michigan Law Review 2054, 2061.
} 
ontological $^{24}$-- and anti-theoretical -- mindset which came to dominate international legal scholarship in the second half of the 20th century. ${ }^{25}$ For the same reason, the ruleness of the sources of international law can be seen as 'surrender' ${ }^{26}$ in front of the daunting difficulty of explaining the foundations of the international legal system, its argumentative practices, and its discourses from sociological and theoretical perspectives.

The idea of rules in the sources of international law is probably also attractive because it seems to generate normativity - i.e. a reason for compliance - and to reinforce the authority of the sources of international law themselves among those involved in the practice of law-ascertainment, that is, in the practice of recognition. ${ }^{27}$ In other words, the ruleness of the sources makes the latter seem more 'obligation-imposing' for legal officials. ${ }^{28}$ Although such an approach to normativity can be called into question, ${ }^{29}$ many international lawyers feel they need ruleness to explain the bindingness of the sources in the first place. This does not mean that they necessarily think that a rulebased understanding of sources of international generates the determinacy that is needed to uphold the authority of a rule. ${ }^{30}$ There seems to be agreement that a rule-based theory of sources exacerbates the general indeterminacy of international law. ${ }^{31}$ The point here is rather that ruleness of the sources of international law generally conveys an impression that the law-identification criteria put in place by the

\footnotetext{
${ }^{24}$ It could be argued that the emergence of the doctrine of sources was itself a first step in this direction for it sought to objectivise once and for all the identification of international legal rules. See D Bederman, Globalization and International Law (Palgrave Macmillan 2008) 45; see also T Skouteris, The Notion of Progress in International Law Discourse (LEI Universiteit, Leiden 2008) chapter 3, later published as The Notion of Progress in International Law Discourse (TMC Asser Press 2010).

${ }^{25}$ See M Koskenniemi, 'Repetition as Reform' (1998) 9 EJIL 405, 406; See also D Kennedy, ‘A Rotation in Contemporary Legal Scholarship' (2011) 12 German Law Journal 338.

${ }^{26}$ On the idea of legalism as a surrender outside the context of the sources of international law, see G Simpson, ‘On the Magic Mountain: Teaching Public International Law’ (1999) 10 EJIL 70, 76.

${ }^{27}$ This is a common foundation of rule-based approach to the rule of recognition in legal theory and jurisprudence. See e.g. G Lamond, 'Legal Sources, the Rule of Recognition and Customary Law’ (2014) 59 AJIL 1-24.

${ }^{28}$ The expression is from GJ Postema, A Treatise of Legal Philosophy and General Jurisprudence (Springer 2011) 300.

${ }^{29}$ F Schauer, 'Is the Rule of Recognition A Rule?' (2012) 3 Transnational Legal Theory 1, 4. For some critical remarks, see below section IV.

${ }^{30}$ On the cost of indeterminacy on the legitimacy and authority of (primary) rules, see $\mathrm{T}$ Franck, The Power of Legimacy among Nations (OUP 1990) 53.

${ }^{31}$ See O Corten, Le discours du droit international: Pour un positivism critique (Pedone 2009); A Paulus, 'International Law after Postmodernism' (2001) 14 Leiden Journal of International Law 754. For a discussion of this point, see d'Aspremont, Formalism and the Sources of International Law, 138-142.
} 
sources are compulsory for all authorities applying international law. Some international lawyers may even feel that having rules on sources alleviates the need for a theory of obligation or authority. ${ }^{32}$

Such an inference of bindingness of sources from the ruleness of sources is probably reinforced by the fact that article 38 of the Statute of the International Court of Justice actually functions like a rule for this specific judicial institution. Indeed, article 38 formally limits the law applicable by the Court, thereby creating an internal rule for this adjudicatory body. ${ }^{33}$ This has been confirmed by the Court itself on several occasions. ${ }^{34}$ It would be of no avail to discuss whether article 38 constitutes, within the framework of the Statute, a rule for the Court. ${ }^{35}$ What matters here is to highlight that this specific internal effect of article 38 has led many international lawyers to generalise the rulebased normativity of article 38 and to transpose it to the sources of international law beyond the specific framework of the Statute of the International Court. Correspondingly other tribunals frequently refer to article $38 .^{36}$

Besides the association between bindingness and ruleness of sources, the success of the rule-based theory of sources of international law can also be explained by the canonical reading given to article 38 of the Statute of the International Court. ${ }^{37}$ It is undeniable that every branch of international law rests on some mechanically repeated canons which serve as foundational authoritative texts and which are determinative of the main 'values' of the field and of its main narrative. Whilst the so-called law of statehood is built on the 1933 Montevideo

\footnotetext{
${ }^{32}$ D Bederman, The Spirit of International Law (University of Georgia Press 2002) 48.

33 Pellet, Article 38, 759; P-M Dupuy, 'La pratique de l'article 38 du Statut de la Cour internationale de Justice dans le cadre des plaidoiries écrites et orales' in Collection of Essays by Legal Advisers of States, Legal Advisers of International Organizations and Practitioners in the Field of International Law (United Nations 1999) 377, 379; Weil, Le droit international en quête de son identité, 139.

${ }^{34}$ Continental Shelf (Tunisia/Libya), ICJ Rep 1982, para. 23; Nicaragua, ICJ Rep 1986, para. 187; Frontier Dispute (Burkina Faso/Mali), ICJ Rep 1986, para. 42; Gulf of Maine, ICJ Rep 1999, para. 93; Martime Delimitation in the Area Between Greenland and Jan Mayen, ICJ Rep 1993, para. 52; Jurisdictional Immunities, ICJ Reports 2012, para. 55.

${ }^{35}$ This has sometimes been challenged. See Joe Verhoeven who argues that article 38 only gives 'indications' to the Court. See J Verhoeven, 'Considérations sur ce qui est commun. Cours general de droit international public’ (2002) 334 Recueil des cours 109.

${ }^{36}$ For some examples, see Pellet, Article 38, 746-747.

${ }^{37}$ On the canonical value of article 38, see the critical remarks of $\mathrm{H}$ Charlesworth, 'Lawmaking and Sources' in J Crawford and M Koskenniemi (eds), Cambridge Companion to International Law (CUP 2012) 187-202. See also J Klabbers, 'Law-making and Constitutionalism' in J Klabbers, A Peters and G Ulfstein (eds), The Constitutionalization of International Law (OUP 2009) 89. See also Bederman, Globalization and International Law, 47
} 
Convention on the Rights and Duties of States, ${ }^{38}$ and the law of international organisations on the 1949 Advisory Opinion on Reparation for Injuries, ${ }^{39}$ the sources of international law are famously presented, listed, taught and theorised by reference to article $38 .{ }^{40} \mathrm{In}$ this context, it is not surprising that this provision has been taken out of its institutional context and elevated into a sort of constitutional rule about the rules of international law. ${ }^{41}$ Construing article 38 as a metaprovision on sources of international law has further contributed to the prevalence of the idea of ruleness of the sources of international law.

For these and other reasons, the ruleness of sources of international law has thrived in current scholarship without being seriously challenged. In defense of international lawyers, it must be acknowledged that general legal theory has generally not proved very helpful. Indeed, jurisprudential debates about the character of the sources of law have been limited: most of the literature dedicated to this matter discusses whether the rule of recognition is internal or external to a legal order. ${ }^{42}$ It is true that there have been more specific discussions on the conventional character of the rule of recognition, ${ }^{43}$ but most of them have ignored the question of whether the rule of recognition should be envisaged as a rule properly so-called. Among the very few who have grappled with this issue, many have taken positions that remain somewhat obscure ${ }^{44}$ or enigmatic. ${ }^{45}$ Others have

\footnotetext{
${ }^{38}$ For some critical remarks on the law of statehood, see $\mathrm{J}$ d'Aspremont, 'The International Law of Statehood: Craftsmanship for the Elucidation and Regulation of Birth' (2014) 29 Connecticut Journal of International Law (2014) 201-224.

${ }^{39}$ ICJ Rep 1979, p. 174. On the canonical revolution that is allegedly brought about the reparations opinion from the standpoint of international law as a whole, see D Bederman, 'The Souls of International Organizations: Legal Personality and the Lighthouse at Cape Spartel’ (1995-1996) 36 Virginia Journal of International Law 275, 279.

${ }^{40}$ See generally Pellet, Article 38, 731-870.

${ }^{41}$ On the high positivism with which article 38 is usually approached, see the critical remarks of Bederman, The Spirit of International Law, 27 and 47.

42 This is one of the main divergences between Kelsen and Hart according to A Marmor, Philosophy of Law 50.

${ }^{43}$ These debates followed an observation made by Hart in the post-script of the 2nd edition of The Concept of Law where he claims that the rule of recognition 'is in effect a form of judicial customary rule existing only if it is accepted and practiced in the law-identifying and law-applying operations of the courts', adding that 'certainly, the rule of recognition is treated in my book as resting on a conventional form of judicial consensus' (256-66). For a defence of the conventional character of the rule of recognition, see Marmor, Philosophy of Law, 75. See also Postema, A Treatise of Legal Philosophy and General Jurisprudence, 494-495. For a discussion of various forms of conventionalism, see J Dickson, 'Is the Rule of Recognition Really a Conventional Rule?' (2007) 27 Oxford Journal of Legal Studies 373. For an express rejection of the conventional character of the rule of recognition, see $L$ Green, 'The Concept of Law Revisited' (1996) 94 Michigan Law Review 1687, 1697.

${ }^{44}$ See K Culver and M Giudice, Legality's Borders - An Essay in General Jurisprudence (OUP 2010) chapter 5, 143-172. They seem to take a skeptical view on the ruleness of sources although they do not address the issue explicitly.
} 
taken a rather relativist position, contending that it is only a matter of perspective: from the outside, the sources of law are a set of practices whereas, from the inside, to each actor engaged in law-ascertainment they appear as a rule or set of rules. ${ }^{46}$ Nonetheless, a handful of skeptics have taken an explicitly hostile position towards the ruleness of the rule of recognition and must be mentioned. ${ }^{47}$ Part IV below will revert to the lessons that can be learnt from these sceptical accounts and the possible insights that can be transposed to international law. It suffices for the moment to indicate that the scepticism of these authors has unfortunately failed to catch the attention of international lawyers. The few international lawyers who have taken pains to reflect upon the theory of the sources of international law have continued to rely primarily on Hart. ${ }^{48}$ This has not proved conducive to a critical reflection on the dominant ruleness of the sources of international law,

${ }^{45}$ See e.g. Postema, A Treatise of Legal Philosophy and General Jurisprudence. He argues that 'the rule of recognition is a genuine rule, but it is a social rule, existing by virtue of the fact that it is practiced inter alia by law-applying officials' (301). He subsequently contends: 'if the practice of officials converges on a certain regular pattern and these shape their reciprocal expectations, then, in circumstances of social interaction structured in this way, there is normative pressure on each official to follow the patterns' (494).

${ }^{46}$ Ibid 496. For a discussion of this position, see below section IV.

${ }^{47}$ See AWB Simpson, 'The Common Law and Legal Theory' in AWB Simpson (ed.), Oxford Essays in Jurisprudence (Second Series 1973) 77; F Schauer, Playing by the Rules (Clarendon Press 1991) 199; See also F Schauer, 'Amending the Presuppositions of a Constitution in S Levinson (ed.), Responding to Imperfection (Princeton University Press 1995) 145, 150-151: 'In referring to the ultimate rule of recognition as a rule, Hart has probably misled us. There is no reason to suppose that the ultimate source of law need be anything that looks at all like a rule, whether simple or complex, or even a collection of rules...The ultimate source of law, therefore, is better described as the practice by which it is determined that some things are to count as law and some things are not'. See also Schauer, Is the Rule of Recognition A Rule?, 1

${ }^{48}$ International lawyers generously refer to Hart. To cite only a few examples, see the general courses of P-M Dupuy 'L'unité de l'ordre juridique international - Cours général de droit international public' (2002) 297 Recueil des cours 9-490; Weil, Le droit international en qunte de son identité, 9-370; G Abi-Saab, 'Cours général de droit international public' (1987-III) 207 Recueil des cours 9-463; O Schachter, 'International Law in Theory and Practice: General Course in Public International Law’ (1982-V) 178 Recueil des cours 1-395. For a significant exception, see Ian Brownlie who discards Hart as too abstract and adopts a much more pragmatic conception of international law, drawing on the assumption that those in charge usually do not even understand law as a unitary concept. For Brownlie, there is not such a thing as a 'neat ultimate rule of recognition which provides an intellectual basis for a system of rules but a complex state of political fact': I Brownlie 'International law at the fiftieth anniversary of the United Nations : general course on public international law' (1995) 255 Recueil des cours 9, 24. In a way that seems to indicate that he construed Hart's theory as a theory of obedience and not a theory of law-ascertainment, Brownlie also formulates the objection that the population may decide to abide by other rules of recognition: Ibid 25. For another rejection of Hart and the defense of a Kelsenian understanding of international law, see J Kammerhofer, 'Uncertainty in the Formal Sources of International Law: Customary International Law and Some of its Problems' (2004) 15 EJIL 523, esp. 543-547. His views are further elaborated in Kammerhofer, Uncertainty in International Law, esp. 205 et seq. and 224 et seq. 
given Hart's studied ambiguity on the character of the rule of recognition. ${ }^{49}$ Indeed his qualifying the rule of recognition both as a social rule ${ }^{50}$ and a pattern of conduct ${ }^{51}$ has sent a contradictory message to his readers.

To some extent, the success of the idea of rules in the sources of international law among international lawyers could surprise. It does not take much jurisprudential proficiency to grasp the difficulty of explaining the foundations of the rules on sources by reference to another layer of rules. Such an approach is not, strictly speaking, selfreferential as the first order ruleness is not meant to be self-justifying or self-explanatory. Rather, the ruleness of sources is supposed to be grounded in another and different layer of (meta-) rules. As a result, a problem of infinite regress arises. Such an infinite regress is inherent in a rule-based approach to sources: should the foundations of rules on sources be itself a rule, the question of the foundation of sources repeats itself ad infinitum. ${ }^{52}$ But this problem of infinite regress has not sufficed to make international lawyers realise the fragility of a rule-based approach to sources. Perhaps the problem of infinite regress may have seemed so insoluble to many international lawyers that they have preferred to ignore it. ${ }^{53}$

It is true that a number of scholars have come to realise the problem of infinite regress. But the problem of infinite regress was not invoked to challenge the dominant ruleness of the sources of international law but rather to vindicate a wide variety of alternative approaches to international law as a whole. For some it brought about a return to the idea of natural law foundations of international law; ${ }^{54}$ to others, pleas for a deformalisation of international law-ascertainment, ${ }^{55}$

\footnotetext{
49 The imprecision of Hart's way of writing is a current and well-known criticism. See Postema, A Treatise of Legal Philosophy and General Jurisprudence, 298-299

${ }^{50}$ See Hart, The Concept of Law, 94-95, 110-112. See also, his postscript, 256-66. For a reading of Hart as the proponent of an anti-rule based approach to the rule of recognition, see Lamond, Legal Sources, the Rule of Recognition and Customary Law, 1-24.

${ }^{51}$ Hart, The Concept of Law, 55-7.

${ }^{52}$ Besson, Theorizing the Sources of International Law, 163, 181. N Onuf, 'Law-making in the Global Community: A Working Paper (1974)' in N Onuf (ed.), International Legal Theory: Essays and Engagements 1966-2006 (Routledge 2008) 63, 80.

${ }^{53} \mathrm{~N}$ Onuf, Law-making in the Global Community, 77 ('the logical problem is so obvious, but apparently, unanswerable, that is as much ignored in the literature on the sources of international law as it is debated in legal social philosophy').

${ }^{54}$ G Fitzmaurice, 'Some Problems Regarding the Formal Sources of International Law', in Symbolae Verzijl (Martinus Nijhoff 1958) 160.

${ }^{55}$ Here, deformalisation is construed as the resort to non-formal yardstick to ascertain international legal rules. See more gen. J d'Aspremont, 'The Politics of Deformalization in International Law’ (2011) 3 Goettingen Journal of International Law 503-550. For a
} 
uncompromising moves away from the very idea of sources, ${ }^{56}$ or turns to empiricism, ${ }^{57}$ or legitimacy. ${ }^{58}$

But I will argue that it is possible to repudiate the idea of ruleness of the sources of international law without simultaneously engaging in any of these more-or-less radical turns. I will make the case for a ruleless foundation of the sources of international law, thereby providing an avenue to skirt round the conceptual pitfalls associated with the idea of rules in the sources of international law.

\section{MOVING AWAY FROM FIRST ORDER RULENESS: A COMMITMENT TO THE 'SOCIAL'}

Needless to say, debunking the dominant view of the ruleness of the sources of international law while salvaging the theory of sources cannot be done in a vacuum. The doubt voiced here against the idea of rules is grounded in a commitment to a social theory of sources. ${ }^{59}$ It is this commitment to 'the social' that offers a platform from which the

different understanding of deformalisation, see M Koskenniemi, 'The Fate of Public International Law: Between Technique and Politics’ (2007) 70 Modern Law Review 1.

${ }^{56}$ Nicholas Onuf has proposed to focus on a theory of artifact making rather than a theory of sources. Onuf, Law-making in the Global Community 63-98 and N Onuf, 'Do Rules Say What They Do? From Ordinary Language to International Law’ (1985) 26 Harvard Journal of International Law 385. In another fashion, Ingo Venzke has calls for a theory of semantic authority rather than a theory of sources: see I Venzke, How Interpretation Makes International Law, On Semantic Change and Normative Twists (OUP 2012) 16-71.

${ }^{57}$ For some examples, see JE Alvarez, International Organizations as Law-makers (OUP 2005); J Brunnée \& SJ Toope, 'International Law and Constructivism, Elements of an International Theory of International Law' (2000-2001) 39 Columbia Journal of Transnational Law 19, 65; M Reisman, 'International Law-Making: A Process of Communication’ (1981) 75 ASIL Proceedings 101; Higgins, Problems and Process, 8-10; PS Berman, 'A Pluralist Approach to International Law' (2007) 32 Yale Journal of International Law, 301; DM Johnston, 'Functionalism in the Theory of International Law' (1988) 26 Canadian YBIL 3, esp. 30-31. For a specific study and evaluation of such a phenomenon, see d'Aspremont, The Politics of Deformalization in International Law, 503550 .

58 See Franck, The Power of Legimacy among Nations. For criticism of the turn to legitimacy and the imposition of empirical political science, see $\mathrm{M}$ Koskenniemi, 'Constitutionalism as Mindset: Reflections on Kantian Themes about International Law and Globalization' (2006) 8 Theoretical Inquiries in Law 9, 14. See also, M Koskenniemi, 'International Law Theory and Doctrine', Max Planck Encyclopedia of Public International Law, para. 22. See also the critical remark of Besson, Theorizing the Sources of International Law, 174.

${ }^{59}$ In our time it is widely believed that paradigmatic choices cannot rely on faith or truth. They are supposed to result from a commitment. See M Koskenniemi, The Politics of International Law (Hart Publishing 2011) 272-3. See the critical remarks by A Carty, Language Games of International Law: Koskenniemi as the Discipline's Wittgenstein, (2012) vol.13 (2) Melbourne Journal of International Law pp.1-20, at 10. . 
dominant ruleness of the sources of international law can be called into question. $^{60}$

Before spelling out the social theory of sources against the backdrop of which the parable of ruleness is faulted, it is necessary to point out that the 'social' in the sources of international law informing the argument made here should not be conflated with a traditional voluntarist approach. ${ }^{61}$ It is true that voluntarism, to the extent that it has ever been defended by scholars, ${ }^{62}$ can also be seen as being a commitment to the social. Yet, the commitment to the social envisaged here is very different. ${ }^{63}$ The commitment to the social derives the lawascertainment criteria provided by the sources of international law from the social practice of those authorities who apply them. According to such a social theory of sources, this means that practice of law-applying authorities, and not the will of States, is what nourishes the sources of international law. Although those authorities may include State officials, they are not limited to them. ${ }^{64}$ Moreover the role of States in generating this social practice is at best secondary, and certainly more difficult to apprehend than in making of primary rules. The social theory of sources that provides the platform from which the ruleness of sources is repudiated here simply presupposes that techniques of lawascertainment are nurtured by the practice of all those involved in identifying rules of international law.

A second preliminary remark: Forsaking the dominant ruleness of the sources of international law by virtue of a social theory of sources is certainly not unprecedented. The idea of a social and extra-legal

\footnotetext{
${ }^{60}$ S Fish, Doing What comes Naturally (Duke University Press 1989) 29-30: "The point of anti-foundationalism is not that there are no foundations: but that whatever foundations there are (and there always are some) have been established by persuasion, that is, in the course of argument and counter-argument on the basis of examples and evidences that are themselves cultural and contextual”.

${ }^{61}$ For an example of a conflation between sources and voluntarism, see Venzke, How Interpretation Makes International Law, 1-2. For an attempt to rejuvenate voluntarism, see T Christakis, 'Human Rights from a Neo-Voluntarist Perspective', in J Kammerhofer and J d'Aspremont (eds), International Legal Positivism in a Post-Modern World (CUP 2014 forthcoming).

${ }^{62}$ The idea that crude voluntarists have never existed and that voluntarism has been a straw man is discussed in $\mathrm{J}$ Kammerhofer and $\mathrm{J}$ d'Aspremont (eds), International Legal Positivism in a Post-Modern World. (CUP 2014 forthcoming). See in particular the chapter of R Collins, 'Classical Positivism in International Law Revisited' in that volume. For a similar distinction, see Besson, Theorizing the Sources of International Law, 166.

${ }^{63}$ See M Koskenniemi, From Apology to Utopia (CUP 2005). It is true that any commitment to the social leads international lawyers to demand less from the world: see $\mathrm{F}$ Megret, 'International Law as Law', in J Crawford and M Koskenniemi (eds), Cambridge Companion to International Law (CUP 2012) 64, 77.

${ }^{64}$ d'Aspremont, Formalism and the Sources of International Law, chapter 8, 195-220.
} 
foundation of sources has long been advocated both in British analytical jurisprudence and Scandinavian realism. ${ }^{65}$ Indeed, the ruleless social theory of sources promoted here is informed by a conception of sources similar to that defended by Salmond ${ }^{66}$ as well as Hart and his followers. The paradox is that the same jurisprudence has contributed to the dominance of the idea of rules in the sources of international law.

The standard account of the social understandings of sources is well-known. ${ }^{67}$ It suffices to highlight two features of the commitment to the 'social'. The first is its dynamic character. By definition, the application of a theory of sources produces a static snapshot of rules existing at the moment of cognition. The static character of the product of the application of the sources of international law is precisely what allows it to fulfil some of its functions, e.g., indicating the applicable law in a contentious case before an international tribunal. While the product of the application of the sources of international law is by definition static, the law-ascertainment criterion need not be so and can evolve with the social practice. In other words, although geared towards a static result, i.e., a snapshot of existing rules at a given time, the social theory of sources depicted above is in itself dynamic as its rules of recognition fluctuate and change along with the practice of lawascertainment by international law-applying authorities. ${ }^{68}$ This means, more specifically, that the social practice can produce law-ascertainment criteria beyond that mainstream model conveyed under the banner of article 38 of the Statute. In that sense, the social theory of sources

\footnotetext{
${ }^{65}$ See A Ross, A Text Book of International Law (Longmans 1947) 83 ('the doctrine of the sources can never rest on precepts contained in one among the legal sources the existence of which the doctrine itself was meant to prove. The basis of the doctrine of legal sources is in all cases actual practice and that alone. The attempt to set up authoritative precepts for the sources of law must be regarded as later doctrinal reflections of the facts which often are incomplete or misleading in the face of reality'). For an adoption of the doctrine in international law, see M Sørensen, Les sources du droit international: étude sur la jurisprudence de la Cour Permanente de Justice Internationale (Munskgaard 1946).

${ }_{66}$ John William Salmond long before Hart derailed Austin for good. Indeed, Salmond had already proposed a theory moving away from Austinian methodology. He refused to identify law with the exercise of state coercive power, on which view law is confused with imperative law. Prefiguring Hart, he contended that the validity of law is strictly a function of judicial recognition and this recognition is a matter of social fact. The ultimate rule of validation is not derived or postulated but lies in the facts of the unified recognition practice of courts. The most glaring difference between the two is probably that, for Salmond, courts have a moral obligation to recognise these principles in virtue of their oath of office but there is no legal obligation to do so. See JW Salmond, Jurisprudence: or the Theory of the Law (7th edn, Sweet and Maxwell 1924) 49-54; JW Salmond, First Principles of Jurisprudence (Stevens and Haynes 1893) 83.

${ }^{67} \mathrm{~J}$ d'Aspremont, 'Reductionist Legal Positivism in International Law' (2012) 106 ASIL Proceedings 368.

${ }^{68}$ On the dynamic character of Hartian conception of law, see W van der Burg, 'Two Models of Law and Morality' (1999) 3 Associations 61, 68.
} 
makes it possible for source theory to develop so as to accommodate the new pluralised forms of public authority which currently cannot be apprehended by the mainstream doctrine of sources. ${ }^{69}$

In such a dynamic framework, evolution and changes in the sources of international law are guided by law-appliers' agendas, ${ }^{70}$ and, more fundamentally, by whom the observer elects as a law-applier, ${ }^{71}$ which itself depends on the observer's agenda and normative choices. Obviously, the determination of the law-applier that is in a position to generate social practice is most contentious, for one can shape the sources of international law - and thus the international lawascertainment criteria - just by redefining the notion of law-applier. There is undoubtedly a real exercise of power in such a definitional exercise. $^{72}$ But that is irrelevant here. It should only be highlighted that there seems to be growing support for the idea that the distinction between citizens and officials does not work on the international plane and that a more inclusive approach to the concept of law-applier is required. ${ }^{73}$ Such a pluralistic understanding of the notion of law-applier could go as far as including, not only states themselves ${ }^{74}$ but also other actors - the International Law Commission, the Institut de Droit international, the International Committee of the Red Cross, etc. ${ }^{75}$ Such a pluralisation of the notion of international law-applier seems to follow similar moves advocated in general jurisprudence with respect to the notion of legal official. ${ }^{76}$

69 But see B Kingsbury \& M Donaldson, 'From Bilateralism to Publicness in International Law’, in U Fastenrath et al (eds), Essays in Honour of Bruno Simma (OUP 2011) 79, 89.

${ }^{70}$ Meyer is right to highlight that there is a normative dimension in FISL. See Meyer, Towards a Communicative Theory of International Law, 10.

${ }^{71}$ See d'Aspremont, Formalism and the Sources of International Law, 195-220. In this question in relation to international law, see also Nardin, Law, Morality and the Relations of States, 158-161. For an extensive concept of law-applying authority, see van der Burg, Two Models of Law and Morality, 63-4. For a pluralistic account of the concept of lawapplier and a move away from State officials, see Culver and Giudice, Legality's Borders; BZ Tamanaha, A General Jurisprudence of Law and Society (OUP 2001) 142. On checksand-balances between international law professionals, see A Somek, 'The Indelible Science of Law’, University of Iowa Legal Studies Research Paper Number 09-18, June 2010.

${ }^{72}$ Fish, Doing What Comes Naturally, 23-24.

${ }^{73}$ Prost, The Concept of Unity in Public International Law,128. See also d'Aspremont, Formalism and the Sources of International Law, esp. 209-213.

${ }^{74}$ See e.g. First Report on the Formation and evidence of customary international law by Michael Wood, para. 50 (according to which states themselves are considered generator of social practice for the theory of sources).

${ }^{75}$ See the discussion in d'Aspremont, Formalism and the Sources of International Law, 209-213.

${ }^{76}$ See Culver and Giudice, Legality’s Borders; Tamanaha, A General Jurisprudence of Law and Society, 142. 
A second important feature of this commitment to the social must be highlighted, namely that the social practice that feeds into the lawascertainment validators of the sources of international law is an interpretative process. In other words, the practice of those applying and identifying international legal rules rests on an act of interpretation, i.e. the interpretation of those law-ascertainment yardsticks or practices which the law-appliers perceive as being authoritative in the community in question. It is important, however, to distinguish law-ascertainment interpretations from the act of interpretation by which the law-applier determines the content of rules. ${ }^{77}$ It is true that interpretation in international law is often reduced to the second of these processes, i.e. content-determination interpretation. ${ }^{78}$ Yet, such an exclusive focus on content-determination obscures the point that what qualifies as a legal rule itself involves interpretation. ${ }^{79}$ When ascertaining the law, the judge, counsel, academic, activist, adviser or even the remote observer necessarily interprets some pre-existing standard of identification of law. This is what has elsewhere been called the phenomenon of 'existential interpretation' ${ }^{80}$ or 'law-ascertainment interpretation'.

\section{APPREHENDING THE SOCIAL: THE TEMPTATION OF SECOND ORDER RULENESS}

Needless to say, a commitment to the social is certainly not the end of the matter. ${ }^{82}$ But this is precisely where most of the discussion begins. ${ }^{83}$

\footnotetext{
${ }^{77}$ The difficulty to distinguish them is exacerbated in that they may operate simultaneously in practice: see O Corten, Méthodologie du droit international public (Editions de l’Université Libre de Bruxelles 2009) 213.

${ }^{78}$ See the literature examined by See M Waibel, 'Demystifying the Art of Interpretation' (2011) 22 EJIL 571.

${ }^{79}$ Mainstream theories of interpretations in international law have, like the theory of sources, been dominantly rule-based in the sense that they have conveyed the idea that content-determination interpretation is carried out by reference to formal rules. See e.g. $\mathrm{R}$ Gardiner, Treaty Interpretations (OUP 2008) 33-38; A Orakhelashvili, The Interpretation of Acts and Rules in Public International Law (OUP 2008) 308-317; P Reuter, Introduction au Droit des Traites (3rd edn, Presses Universitaires de France 1995) 88. And cf. A Bianchi, 'Textual Interpretation and (International) Law Reading: The Myth of (in) Determinacy and the Genealogy of Meaning', in P Bekker Making (ed), Transnational Law Work in the Global Economy (CUP 2010) 35. See however G Hernandez who speaks about interpretation as 'a set of shared vocabularies and techniques which are to be mastered by international lawyers for international lawyers': G Hernandez, 'Interpretation' in J Kammerhofer and J d'Aspremont (eds), International Legal Positivism in a Postmodern World (CUP 2014 forthcoming).

${ }^{80} \mathrm{D}$. Hollis, 'The existential function of interpretation in international law', in A Bianchi, D Peat and M Windsor (eds.), Interpretation in International Law (OUP 2015 forthcoming).

81 See J d'Aspremont, 'The Multidimensional Process of Interpretation: ContentDetermination and Law-Ascertainment Distinguished', forthcoming in A Bianchi, D Peat and M Windsor (eds.), Interpretation in International Law (OUP 2015 forthcoming).

${ }^{82}$ D Kennedy, 'The Disciplines of International Law and Policy' (1999) 12 Leiden Journal of International Law 9, 13.
} 
Indeed, the commitment to the social does not suffice in itself to do away with the idea of rules in the sources of international law, for, when one starts to describe and apprehend the interpretive practice that nurtures the sources of international law, the idea of rule immediately returns. Smothered for a moment, the idea of rules resuscitates upon the capture of the 'social'. ${ }^{84}$ When this is the case, the respite from ruleness offered by a grounding of the sources in the social can prove short-lived.

This temptation of a return to ruleness despite the grounding of the sources in the social can be explained as follows. If the sources originate in a social (interpretive) practice, one is confronted with the need to elect one's conceptual framework to apprehend and (re)construct the relevant social (interpretive) practice. Yet there is no preconceived practice; ${ }^{85}$ only the practice constructed by virtue of a preconceived conceptual framework. ${ }^{86}$ All descriptive language is necessarily 'paradigmatic-specific ${ }^{97}$, there being no other way to look at the world. ${ }^{88}$ One needs to choose a 'value-fact ${ }^{89}$ to construct practice. The same holds for the interpretive practice that feeds in the sources of international law. ${ }^{90} \mathrm{~A}$ choice of a conceptual framework is thus presupposed before one can try to apprehend any practice.

When choosing the 'value fact' by which to construct the interpretative practice generative of the law-ascertainment yardsticks, rules prove to be a convenient and obvious category to create stability and intelligibility. ${ }^{91}$ More precisely, rules constitute a stabilising category

\footnotetext{
${ }^{83}$ See Singh, International Law as a Technical Discipline.

${ }^{84}$ This is a traditional objection made against Fish. See P Schlag, 'Fish v, Zapp: The Case of the Relatively Autonomous Self' (1987) 76 Georgetown Law Journal 42.

${ }^{85}$ A McIntyre, Whose Justice? Which Rationality? (Duckworth 1988) 333.

${ }^{86}$ Mark Greenberg, 'How Facts Make Law' (2004) 10 Legal Theory 157, esp. 160-1; Fish, Doing What Comes Naturally, 11; Kuhn, The Structure of Scientific Revolutions, 37; P Capps, Human Dignity and the Foundations of International Law (Hart 2009) 76; A Peters, 'Realizing Utopia as a Scholarly Endeavor' (2013) 24 EJIL 1-20; See also the discussion by BB Levenbook, 'How to Hold the Social Fact Thesis - a Reply to Greenberg and Toh', North Carolina State University Working Paper 2010.

${ }^{87}$ Fish, Doing What Comes Naturally, 143 (citing Thomas Kuhn).

${ }^{88}$ Ibid 488.

${ }^{89}$ M Greenberg, How Facts Make Law.

${ }^{90}$ This is why Hart's theory has been deemed evaluative. See also SR Perry, 'Hart's methodological positivism’ (1998) 4 Legal Theory 427, 438 and 466. For a discussion of this argument see J Dickson, Evaluation and Legal Theory (Hart Publishing 2001) 35-6; R Blanco, 'The Methodological Problem in Legal Theory: Normative and Descriptive Jurisprudence Revisited' (2006) 19 Ratio Juris 26.

${ }^{91}$ That does not mean a rule-based foundation is necessarily an easy and convenient one. It 'is not merely a linguistic doctrine, but a doctrine that implies, in addition to a theory of language, a theory of the self, of community, of rationality, of practice, of politics': Fish, Doing What Comes Naturally (referring to Roberto Unger).
} 
to cognise, apprehend and organise the interpretative practice of lawascertainment which is supposed to feed into the sources. ${ }^{92}$ They allow the observer with a social theory of sources to see those involved in the business of law-ascertainment as applying pre-defined rules. The practice of all those authorities identifying international law and determining which rules are international legal rules and which is thus constructed as being the application of rules on the ascertainment of law.

As this makes clear, the ruleness here does not lie with the sources of international law themselves but with the prior concept of the social. Ruleness is thus not found in the sources themselves but in the framework to establish their social foundations. This is second order ruleness. It will not come as a surprise that, like the first-order ruleness of sources, the return to rules to apprehend the social foundations of sources comes with an inevitable element of circularity. Indeed, the 'social' is constructed and apprehended by the very rules it is meant to nurture. It is no coincidence that a similar charge of circularity was raised against Hart's idea of secondary rules. ${ }^{93}$ Such circularity however produces a type of infinite regress different from the one traditionally associated with the first order ruleness of sources. In fact, whilst first order ruleness generates an infinite need of foundational rules, ${ }^{94}$ second order ruleness, that is ruleness for the apprehension of the social, calls for new rules to guide the interpretation of the rules through which the social practice is apprehended, such rules being themselves in need of interpretative rules (and thus not being self-referential but in need of other rules). ${ }^{95}$ To each type of ruleness corresponds a different type of infinite regress.

\footnotetext{
92 Jean d'Aspremont. 'Formalism versus Flexibility in the Law of Treaties' in C Tams, A Tzanakopoulos and A Zimmermann (eds), Research Handbook on the Law of Treaties (Edward Elgar 2014); see also J d'Aspremont, 'The Multidimensional Process of Interpretation.

${ }^{93}$ Matthew H Kramer, 'The Rule of Misrecognition in the Hart of Jurisprudence' (1988) 8 Oxford Journal of Legal Studies 401, 407; J Beckett, 'The Hartian Tradition in International Law' (2008) 1 The Journal of Jurisprudence 51, 58; A Marmor, 'Farewell to Conceptual Analysis (In Jurisprudence)' USC Legal Studies Research Paper No. 12-2 (23 January 2012), 24; Culver and Giudice, Legality’s Borders, 8-14; Marmor, Philosophy of Law, 56. On this point, see Neil MacCormick's defence of Hart (MacCormick, Legal Reasoning and Legal Theory (Clarendon Press 1978). On MacCormick's so-called postpositivism, see K Petroski, 'Is Post-Positivism Possible?' (2011) 12 German Law Journal 663, 665.

${ }^{94}$ See section I above.

${ }^{95}$ Venzke, Post-Modern Perspectives on Orthodox Positivism. This objection of infinite regress is classically raised in connection to the rules on interpretation of treaties. On this problem in the specific context of treaty interpretation, see gen. Bianchi, Textual Interpretation and (International) Law Reading, 35.; See also G Letsas, 'Strasbourg's Interpretive Ethics Lessons for the International Lawyer’ (2010) 21 EJIL 509, 534.
} 
But the charges of circularity and infinite regress are unwarranted as long as second order ruleness can be repudiated. It is the aim of the following section to demonstrate the possibility to ground the sources of international law in law-ascertainment interpretation without falling in the pitfalls of first and second order ruleness to apprehend the social.

\section{RESISTING FIRST AND SECOND ORDER RULENESS: THE TURN TO COMMUNITARIAN CONSTRAINTS}

Obviously, there are many ways in which the idea of community in international law could be construed. Until recently, international lawyers tended to look at the community organised around international law through the angle of law-appliers, ${ }^{96}$ the beneficiaries of law, ${ }^{97}$ the auctoritatis interpositio, ${ }^{98}$ or other undeveloped notions like the 'invisible college'. ${ }^{99}$ But other cognitive models have come to stand out, some of them inherited from other social sciences. It suffices to mention two of them before spelling out the one which proves the most supportive of the idea of rulelessness in sources of international law. ${ }^{100}$

From international relations theory, international lawyers have learnt that that their community can be understood as an epistemic community, that is unsystematic network of professionals with recognised expertise and authority that allow them to contribute policyrelevant knowledge in relation to their area of expertise. ${ }^{101}$ According to

\footnotetext{
${ }^{96}$ The notion of the 'law-applier' emerged in the context of rule-based approaches to international law. It finds roots in British analytical jurisprudence as well as German legal positivism. It quickly proved insufficient because it was equated with the idea of judicial authority, very much the exception, not the rule, in international law. In recent years, the concept of law-applying authority has been subject to some dilution and pluralisation in general jurisprudence. See Culver \& Giudice, Legality’s Borders.

${ }^{97}$ See e.g. R McCorquodale, 'An Inclusive International Legal System’ (2004) 17 Leiden Journal of International Law 477.

${ }^{98}$ The idea of auctoritatis interpositio is borrowed from Carl Schmitt although it is used to refer to the Kantian idea - systematised by Kelsen - that by virtue of the indeterminacy of rules, law is ultimately dependent upon human judgment. See C Schmitt, Politische Theologie: Vier Capital zur Lehre von der Souveranitat (Duncker und Humblot 1979) 41. See the discussion of that question by N. Rajkovic, 'Rules, Lawyering, and the Politics of Legality: Critical Sociology and International law’s rule’ (2014) 27 Leiden Journal of International Law 331.

${ }^{99}$ O Schachter, 'The Invisible College of International Lawyers’ (1977-1978) 72

Northwestern University Law Review 217.

${ }^{100}$ For a discussion of the various parameters that allow a differentiation between the community of lawyers and the rest of the society, see, F Schauer, The Force of Law (Harvard University Press 2015 forthcoming) chapter 11. See more generally N Luhmann, The Differentiation of Society (Columbia University Press 1984).

${ }^{101} \mathrm{P}$ Haas, 'Introduction: epistemic communities and international policy coordination' (1992) 46 International Organizations 1, 2 and 3 (Peter Haas acknowledges that the notion
} 
this construction, international lawyers constitute an epistemic community, and not merely an interest group, a social movement or even a discipline, by virtue of a shared faith in certain - allegedly scientific - methods as a way of generating truth. ${ }^{102}$ The notion of epistemic community has proved appealing for many international lawyers to explain some of the dynamics at work in the creation of knowledge about international law. ${ }^{103}$

From another strand of international relations, international lawyers have borrowed the more fluid and open idea of community of practice. According to that construction, international lawyers constitute a community insofar as they 'are informally as well as contextually bound by a shared interest in learning and applying a common practice ${ }^{104}$ while also sharing a common 'repertoire of communal resources, such as routines, words, tools, ways of doing things, stories, symbols, and discourse'. ${ }^{105}$ This presupposes 'social communication through which practitioners bargain about and fix meanings and develop their own distinctive identity and how to practice it'. ${ }^{106}$ The concept of community of practice is more fluid in that the members' shared sense of joint enterprise is constantly being renegotiated ${ }^{107}$ and membership is not fixed as members constantly move in and out. ${ }^{108}$ It seems possible to say, with some risk of oversimplification, that communities of practice constitute a more all-encapsulating notion than that of epistemic community, the latter being a special kind of community of practice. In this context, the doctrine of sources may be considered one of the most elementary tools that allows social practice within the community. ${ }^{109}$

\footnotetext{
has marxist origins, but he uses it in a different way).

102 Ibid 3, 18.

${ }^{103}$ M Noortmann, 'The International Law Association and Non-state Actors: Professional Network, Public Interest Group or Epistemic Community?', in J d'Aspremont (ed.), Participants in the International Legal System: Multiple Perspectives on Non-state Actors in International Law (Routledge 2015 forthcoming) 233; DJ Galbreath \& J McEvoy 'How Epistemic Communities Drive International Regimes: the Case of Minority Rights in Europe' (2013) 35 Journal of European Integration 169; For an application of the notion see P Haas, 'International Environmental Law: Epistemic Communities' in D Bodansky, J Brunée and E Hey (eds), The Oxford Handbook of International Environmental Law (OUP 2007) 791-806.

${ }^{104}$ E Adler, Communitarian International Relations: The Epistemic Foundations of International Relations (Routledge 2005) 15.

105 Ibid.

${ }^{106}$ Ibid, 17

${ }^{107}$ Ibid, 14

108 Ibid.

${ }^{109}$ H Cohen, 'Finding International Law, Part II: Our Fragmenting Legal Community' (2012) 44 NYU Journal of International Law and Politics 1049.
} 
These two cognitive models have their own merits and weaknesses. Each of them sheds light on a different aspect of the community of those socialised as international lawyers. For present purposes a third notion of community, borrowed from literary and linguistic philosophy, seems more relevant. ${ }^{110}$ The notion of interpretive community, first theorised by Stanley Fish, refers to the public and conventional point of view that brings order to the argumentative practice of international law. ${ }^{111}$ It presupposes a common understanding of what constitutes valid practice, such an understanding being occasionally translated into rules, like rules on interpretation or rules on sources of law. According to that notion, international lawyers constitute an interpretive community as soon as they share a language they allows them to speak to one another and an internalised system of principles that comes to constrain the type of legal argumentation they recognise as valid. ${ }^{112}$

The relevance of this specific idea of community for the debate on the rulelessness of the sources of international law is epitomised by the debate between, on the one hand, those who like Owen Fiss ${ }^{113}$ advocate the existence of disciplinary rules to constrain interpretive processes and, on the other hand, those who, like Stanley Fish, ${ }^{114}$ contend that the creation of the social is constrained by the community, not by rules. It will not come as a surprise that the latter's theory is of paramount importance for anyone asserting rulelessness in the sources of law. According to Fish, the 'practice is already principled, since at every moment it is ordered by an understanding of what it is practice (the law, basketball), an understanding that can always be put into form of rules rules that will be opaque to the outsider - but is not produced by them'. ${ }^{115}$ What is more, principles that structure a social interpretive practice 'do not proceed from an isolated individual but from a public

\footnotetext{
${ }^{110}$ For examples of works resorting to the notion of interpretive community, see A Bianchi, 'The International Regulation of the Use of Force: The Politics of Interpretive Method' (2009) 22 Leiden Journal of International Law 651; I Johnstone, 'Treaty Interpretation: The Authority of Interpretive Communities' (1991) 12 Michigan Journal of International Law 371; E Papastavridis, 'Interpretation of Security Council Resolutions under Chapter VII in the Aftermath of the Iraqi Crisis' (2007) 56 ICLQ 83.

${ }^{111}$ S Fish, Is there a text in this class (Harvard University Press 1980) 13-4; S Fish, 'Fish v. Fiss' (1984) 36 Stanford Law Review 1325, 1331-32.

${ }^{112}$ Fish, Is there a text in this class?, 5.

${ }^{113}$ O Fiss, 'Objectivity and Interpretation' (1982) 34 Stanford Law Review 739.

${ }^{114}$ Fish's objection to this concept of disciplinary rules is that disciplinary rules are not necessary because the reader is not in need of the constraints that disciplinary rules would provide: 'The trainee is not only possessed of but possessed by a knowledge of the ropes, by a tacit knowledge that tells him not so much what to do, but already has him doing it as a condition of perception and even of thought' (Fish, Fish v. Fiss, 1333). For him there is no need of constraints because 'texts are structures of constraint' (Ibid 1339).

${ }^{115}$ Fish, Fish v. Fiss, 1331-32.
} 
and conventional point of view' ${ }^{116}$ This public and conventional point of view against the backdrop of which the social practice of law-applying authorities takes place was what Fish identified as the 'interpretive community'. ${ }^{117}$ The concept of 'interpretive community' allows one to construe the social practice that nurtures the sources of international law as being principled by reference to communitarian constraints rather than rules. ${ }^{118}$ It is the community that generates the constraints, for with the community comes an element of continuity and tradition. Those involved in the practice of law-identification, whether as judge, legal advisor or other relevant actor involved in law-identification, anchor their interpretation of what constitutes international law in a pattern inherited from the past which is reconstructed for the situation they face. ${ }^{119}$ As a result of such a communitarian account, the lawascertainment criteria provided by the sources of international law become more a question of 'knowledge' of such constraints by those involved in law-identification rather than a set of rules to which they are subjected. ${ }^{120}$

\footnotetext{
${ }^{116}$ Fish, Is there a text in this class, 14.

${ }^{117}$ Ibid: 'The relationship between interpretation and text is thus reversed: interpretative strategies are not put into execution after reading; they are the shape of reading, and because they are the shape of reading, they give texts their shape, making them rather than, as is usually assumed, arising from them' (13). According to Fish, these 'interpretative strategies' do not make the reader an independent agent. They 'proceed not from him but from the interpretative community of which he is a member' (14). He adds: 'the meanings and texts produced by an interpretive community are not subjective because they do not proceed from an isolated individual but from a public and conventional point of view' (14). This is 'the explanation for the stability of interpretation among different readers (they belong to the same community)' (15).

${ }^{118}$ Ronald Dworkin objected that, construed as a social and communitarian practice, these constraints do automatically reduce the role of the interpreter as a chain novelist. See $\mathrm{R}$ Dworkin, 'Law as Interpretation' (1982) 9 Critical Inquiry 179. It can be argued with Fish and McIntyre, however, that the interpreter is not constrained by the past but recreates it. See the answer to Dworkin by Fish ('Working on the Chain Gang: Interpretation in the Law and in Literary Criticism’ (1982) 9 Critical Inquiry 201.

${ }^{119}$ On this point see M Polanyi, Personal Knowledge. Towards a Post Critical Philosophy (Routledge 1958) 160; see also M Mitchell, 'Michael Polanyi, Alasdair MacIntyre, and the Role of Tradition' (2006) XIX Humanitas 97, 105. According to Koskenniemi, 'This is what traditions do: they try to accommodate new phenomena in patterned, familiar understandings, seeking to balance reverence for the past with openness to the future, with innovators sometimes rejected as degraders, sometimes celebrated as regenerators' (Koskenniemi, Constitutionalism as Mindset, 22).

${ }^{120}$ Fish, Fish v. Fiss, 1329. See however the criticism by Judith Schelly according to which one could no more get out a list of them than one could get out a list of the rules: J Schelly, 'Interpretation in Law: The Dworkin-Fish Debate (or Soccer amongst the Gahuku-Gama)' (1985) 73 California Law Review 158. According to Schelly (163-4), Fish and Dworkin both agree that authority for interpretation comes through processes that are complex, communal, and political. For both of them, interpretations become 'correct' as they become social objects. The ultimate difference between Fish and Dworkin is that for Dworkin morality would constrain interpretation, rather than being created through it, and there always is a right answer. In contrast, for Fish, an epistemic community is not a moral community and the constraints it provides are not moral but political.
} 
Fish's communitarian approach, notwithstanding the possible incommensurability inherent in its transposition to international law, provides decisive support for a theory of sources short of second order ruleness. It underpins a theory of sources of international law constituted by communitarian constraints rather than rules. According to this theory, international judges, domestic judges, legal advisers of States, legal advisers of international organisations, and, possibly, other public or private bodies called on to authoritatively apply international law do so, not on the basis of a set of rules, but by virtue of a set of communitarian constraints. This is so even if they may have the feeling that they are yielding to a 'rule'. Such constraints are known to them by virtue of tradition and training rather than by a set of rules formally imposed. ${ }^{121}$ The feeling of abiding by a rule comes from the socialising role which is played by the doctrine of sources. Acquiring a mastery of the doctrine of the sources of international law is simultaneously what socialises international lawyers and makes them international lawyers. In that sense, there is an inevitable dialectic relation between the community and the sources of international law as they are both constituted by and constitutive of one another. ${ }^{122}$ The approach defended here allows this dialectical relation to operate in the absence of rules.

This communitarian account brings about more than a substitution of communitarian constraints for the rules on the sources of international law. Fish's account simultaneously generates room for dissent and divergences in the practice of the identification of international law. Indeed, the community in which such communitarian constraints are anchored is certainly 'not fixed and finite'. ${ }^{123}$ It fluctuates all the time and the practice it generates evolves accordingly. There thus is a great deal of instability in the constraints on law-identification generated by that community. ${ }^{124}$ The instability inherent in communitarian constraints on the identification of international law constitutes another pivotal distinguishing factor from a rule-based theory of sources which is meant to provide stability. The possibility of fluctuation in law-identification may even be considered the paramount reason to uphold rulelessness in the sources of international law.

\footnotetext{
${ }^{121}$ See however the remarks on article 38 of the Statute of the International Court of Justice above in section II.

${ }^{122}$ On this question, see the introduction of J. d'Aspremont, Epistemic Forces in International Law (Edward Elgar 2014 forthcoming)

${ }^{123}$ Fish, Fish v. Fiss, 1329.

${ }^{124}$ Fish writes that an interpretive community 'can be homogenous with respect to some general sense of purpose and purview, and heterogeneous with respect to a variety of practices it can accommodate': Fish, Doing What Comes Naturally, 149.
} 
Indeed, the blend of instability and continuity can be seen as providing convenient flexibility that 'allows for significant degree of conflict and dissent' while leaving intact the possibility of dissent. ${ }^{125}$ In other words, fluctuations and instability of communitarian constraints do not bar communication, for communication does not necessitate stable meaning. ${ }^{126}$

I suggest that the idea of communitarian constraints found in literary theory offers a framework to construe sources of international law independently from any ruleness. But the support offered by the communitarian account is not entirely watertight. Aspects of that account have been challenged. Some well-known objections have been raised against the rulelessness of Fish and they should be recalled here. In particular, Owen Fiss objected that '(j)ust as one cannot understand or formulate rules unless one is a participant in the practice, so one cannot participate successfully within the practice known as law... unless one is able to understand or formulate the rules governing the practice'. ${ }^{127}$ This invokes the impossibility of standardising the constraints. Fiss added that, because Fish 'rejects the disciplining rules or any general normative standards - he is left without any basis for resolving conflicting interpretations in any principled way'. ${ }^{128}$ Pierre Schlag likewise denounced the failure by Fish to define the set of constraints generated by the interpretive community. According to Schlag, Fish shies away from such a definition because such a descriptive exercise would produce a text which, being rule-like, would contradict his argument. Fish's thesis is pure convenience as it allows him to stop before it leads him to complete deconstruction of the object under analysis. ${ }^{129}$ For Dworkin, the constraints imposed on interpretation are so weak that interpretation remains entirely subjective. ${ }^{130}$ Dennis Patterson, for his part, has alleged that the concept of interpretive community was unstable as it is constantly oscillating between a homogeneous variant and a pluralistic variants to explain

\footnotetext{
${ }^{125}$ Mitchell, Michael Polanyi, Alasdair MacIntyre, and the Role of Tradition, 106.

126 See Singh, referring to de Saussure: 'Common use of a word may permit communication, but use cannot establish the core of a word' (Singh, International Law as a Technical Discipline).

${ }^{127}$ O Fiss, ‘The Jurisprudence (!) of Stanley Fish’ (1985) 80 Ade Bulletin 1, 2.

128 Ibid.

129 Shlag, Fish v. Zapp, 42-9.

${ }^{130}$ G Dworkin, 'My reply to Stanley Fish' in WJT Mitchell (ed.), The Politics of Interpretation (University of Chicago Press 1982) 287, 294.
} 
diverging interpretations. ${ }^{131}$ Others have seen an element of circularity in the concept of interpretive community. ${ }^{132}$

But many of these objections to the idea of communitarian constraints could apply to any modernist pursuit of coherence. ${ }^{133}$ In that sense, they pertain to a much wider debate that pits two irreconcilable approaches against one another. ${ }^{134}$ One is forced to make a choice: in my view, the commitment to the social and the idea of rulelessness in sources of international law are both deeply ingrained in a modernist vision of international law as a normative universe structured around the possibility of right or wrong, of permissible and impermissible, or valid and invalid. ${ }^{135}$ In this universe, the idea of the law-ascertainment made principled by communitarian tradition allows one to explain the phenomenon of law-ascertainment independently of rules. Third, going beyond accounts based on literary theory, insights can also be gleaned from general jurisprudence. Some legal theorists have questioned the ruleness of the rule of recognition and offered support for the repudiation of a rule-based understanding of the sources of international law. Liam Murphy for instance, claims that the rule of recognition is better seen as a 'set of beliefs' ${ }^{136}$ Fred Schauer's restrictive notion of rules ${ }^{137}$ leads him to take a similar position: one should rather

${ }^{131}$ D. Patterson, "You made me do it: my reply to Stanley Fish”, 72 Texas Law Review (1993) 67, esp. 76-77.

${ }^{132}$ For both Polanyi and MacIntyre, as presented by Mitchell, 'belief must necessarily precede knowing'. This brings about 'circularity': one must commit to certain premises and the conclusions reached are necessarily entailed by the premises embraced. See Mitchell, Michael Polanyi, Alasdair MacIntyre, and the Role of Tradition, 109-11.

${ }^{133}$ Some of them are discussed in Kammerhofer \& d'Aspremont, International Legal Positivism in a Post-modern World. On the modernism and universalism that informed the emergence of the theory of sources, see Bederman, Globalization and International Law, 45.

${ }^{134}$ On the irreconcilability of modernism and postmodernism, see S Singh, 'International Legal Positivism and New Approaches to International Law', in J Kammerhofer \& J d’Aspremont (eds), International Legal Positivism in a Post-modern World.

${ }^{135}$ R Cover, 'The Supreme Court 1982 Term -- Foreword: Nomos and Narrative”, 97 Harvard Law Review 4, at 4-5 (1983).

${ }^{136}$ L Murphy, What makes Law, 33 (on file with the author): 'The whole thing makes much more sense if we regard the rule of recognition as no practical rule at all, but rather a simple statement of ultimate criteria that one may hold correct or not. From this perspective, we can read Hart's use of the word 'acceptance' when discussing the rule of recognition as meaning something other than it usually does for him. We can say that the officials must accept that these are the actual ultimate criteria of validity for this legal system in the sense that they must believe that they are, or be disposed to treat them as such'. On p. 35, he adds: 'The better solution is simply to abandon the idea that the rule of recognition exists as a social practice in any straightforward sense. The rule of recognition, if it exists, is a set of common beliefs and or attitudes, perhaps implicit, about the ultimate grounds of law and/or dispositions about what to regard or treat as the ultimate criteria when figuring out what the law is'.

${ }^{137}$ The denial of the ruleness of the rule of recognition is more specifically informed by his contention that the rule of recognition must be based on a justification broader than the rule itself, that is the entrenchment of a generalisation against the inevitable pressure brought 
speak of the 'idea' rather than the 'rule' of recognition. ${ }^{138}$ Brian Simpson speaks of the 'practices' of recognition which he understands as non-rule-based. ${ }^{139}$ For these sceptics, the rulelessness of the theory of sources does not mean there are no constraints but that such constraints are more sociological in character, ${ }^{140}$ and this is so whether they are understood as a set of beliefs, of practices or of ideas.

One particular criticism of rulelessness does require more detailed rebuttal: the charge of relativism. This originates in the common distinction between the internal and external points of views. ${ }^{141}$ According to this distinction, the ruleness of the theory of sources could be reduced to a mere matter of perspective. For the judge who approaches the sources from an internal perspective, sources are perceived as rules. The ruleness is what generates normativity in the perception of the law-applying authorities. Conversely, from the perspective of an external observer to the legal system, the rule of recognition (and hence the theory of sources) need not and should not be construed as rules. ${ }^{142}$

This objection is important. Among the many parameters mentioned in part I, the idea of rules appeals because it generates internal normativity - a reason for law-abidance - and reinforces the authority of the sources of international law among those involved in the practice of law-ascertainment. ${ }^{143}$ Many scholars take a rule-based

\footnotetext{
against the generalisation by its original generative justification. This had led some scholars to see a tension in Schauer's positivism. See A Sebok, 'Is the Rule of Recognition a Rule?' (1997) 72 Notre Dame Law Review 1539.

${ }^{138}$ Schauer, Playing by the Rules, 199; See also F Schauer, 'Amending the Presuppositions of a Constitution' in S Levinson (ed.), Responding to Imperfection (Princeton University Press 1995) 145, 150-1: 'In referring to the ultimate rule of recognition as a rule, Hart has probably misled us. There is no reason to suppose that the ultimate source of law need be anything that looks at all like a rule, whether simple or complex, or even a collection of rules... The ultimate source of law, therefore, is better described as the practice by which it is determined that some things are to count as law and some things are not'.

${ }^{139}$ AWB Simpson, 'The Common Law and Legal Theory', in AWB Simpson (ed.), Oxford Essays in Jurisprudence (Second Series, OUP 1973) 77.

${ }^{140}$ Schauer, Is the Rule of Recognition A Rule?, 7.

${ }^{141}$ For further discussion on this distinction, see J Finnis, 'On Hart's Ways: Law as Reason and as Fact' in M Kramer, C Grant, B Colburn and A Hatzistavrou (eds), The Legacy of H.L.A. Hart: Legal, Political and Moral Philosophy (OUP 2008) 3. For criticisms of the internal perspective, see RB Kar, who argued that Hart's theory must be refined by adding the reference to the second-person standpoint in order to reconcile Hart, Shapiro and Dworkin: RB Kar, 'Hart's Response to Exclusive Legal Positivism', Loyola-LA Legal Studies Paper No. 2007-10.

${ }^{142}$ Postema, A Treatise of Legal Philosophy and General Jurisprudence, 496.

143 This is a common foundation of rule-based approach to the rule of recognition in legal theory and jurisprudence. See e.g. Lamond, Legal Sources, the Rule of Recognition and Customary Law.
} 
approach to the sources of international law to explain why, from an internal perspective, those sources bind in the first place. They find support in article 38 of the Statute of the International Court of Justice: this binding stipulation was not intended, and has not been taken, as a lex specialis. But the appeal of the distinction between internal and external perspectives should not be exaggerated, for several reasons. First, the perspective of the inquiry carried out here is external. It does not seek to evaluate how the actors involved in the business of identifying international legal rules individually or collectively perceive the sources of international law. Second, and more fundamentally, the ruleness which may be felt by law-appliers only raises a question of sources of normativity. It does not explain the foundations of international law. In other words, the criteria of law-identification may well be perceived as binding by law-appliers irrespective of their actual character. The way in which law-appliers construe the bindingness of the sources of law is not determinative. It is no coincidence that, in general legal theory, the ruleness of the sources of international law is most of the time geared towards the authority of sources. Eventually, it should be made clear that ruleness is not the only source of normativity. The sources can be perceived as binding by the law-applier for other motives than its ruleness. ${ }^{144}$ All-in-all, the classical distinction made between internal and external perspectives in jurisprudence and general theory does not seem particularly helpful. And the historical residue that is article 38, even if (which is doubtful) it functions as a formal rule, is inadequate to underpin the ruleness of the sources of international law as a general matter.

\section{CONCLUDING REMARKS}

I have sought to demonstrate that there exists a credible alternative to the dominant view of the ruleness of sources of international law. Seeking refuge in natural law, policy-approaches, deformalisation or embracing a total abandonment of the sources themselves do not constitute the only way out of the infinite regress and circularity inherent in the ruleness of the sources of international law. There is room for a social theory of sources of international law grounded in communitarian constraints which allows for principled argumentation on what constitutes law and non-law in the absence of rules. This means, more concretely, that, when identifying the rules of international law, international judges, domestic judges, legal advisers of States, legal advisers of international organisations, and other public or private bodies called on to authoritatively apply international law generate a

${ }^{144}$ Schauer, Is the Rule of Recognition A Rule?, 4. 
practice of law-ascertainment - that is, a practice of recognition - which then feeds into the sources of international law. These actors may feel that, in doing so, they yield to some pre-existing rules on how to distinguish between law and non-law. But such perceptions are not themselves constitutive of the ruleness of the sources of international law. Rather, what these actors conform to is a set of communitarian constraints and practices which they constantly perpetuate and adjust.

Debunking the ruleness of the sources of international law does not only afford descriptive and explanatory insights. It can have practical implications for practitioners, including judges. Although judges may feel bound by provisions of their respective statutes which deal with sources or offer a list of sources, they should remember that those provisions do not operate as rules, even within the confined normative environment of their court or tribunal. Outside that environment, sources are the expression of evolving practices of a wider community of international lawyers. The argument made here should thus assist judges to come to terms with the inherently dynamic character of sources-based constraints on legal argumentation. There is an increasingly pluralistic community of international lawyers - not only judges - involved in the generation of law-identification practice, and this calls for a greater pluralism in the techniques of law-identification provided by the sources of international law themselves. ${ }^{145}$ Eventually, and although the sources of international law are foundational of the community and of its argumentative language, the account provided here may encourage judges to abandon the pontifical and dogmatic tone which some of them resort to when they deploy (and speak the language of) the sources of international law. The sources, as has been explained here, are the product of a community over which they hold no monopoly.

The approach to sources defended here is neither nihilistic nor anti-foundationalist. It is not suggested that there are no foundations to the sources of international law but rather that the foundations are not to be found in pre-existing rules. Such a conception of the sources of international law remains discernibly modernist, for stripping the sources of international law from the idea of rules is a way to salvage the modernist functions of the sources of international law. In this respect, it should be remembered that the theory of sources of international law

\footnotetext{
145 The identification of international humanitarian law and international criminal law provides an example of this growing pluralism. See J d'Aspremont, 'An Autonomous Regime of Identification of Customary International Humanitarian Law: Do Not Say What You Do or Do Not Do What You Say?' in R van Steenberghe (ed.), Droit international humanitaire: un régime spécial de droit international? (Bruylant 2013) 73.
} 
as it is known, taught and practiced today was designed to allow for universal legal argumentation, avoiding the everlasting and insoluble controversies on the membership of norms in the international legal order. The theory of sources thus epitomised the modernist project of restricting debates to content-determination by virtue of an objectivisation of law-ascertainment. It is well-known that preserving the possibility of argumentation within the confines predetermined by the sources of international law could not be and was not achieved. The sources of international law never delivered on those promises. But they survived nonetheless, largely by virtue of the dominant doctrine of the ruleness of sources. Cast as rules, the sources of international law were allowed to function and were perpetuated in spite of their inefficiency. One may wonder whether there can be anything left of this modernist project, once the sources are dethroned as rules. If demoted to a set of communitarian constraints, can they still perform the modernist functions which they were thought and intended to fulfil a century ago?

The answer lies in the disclosure of the politics of lawascertainment and the preservation of legal argumentation. ${ }^{146}$ The repudiation of the ruleness of the sources of international law advocated here is indeed an attempt to discover the politics of the sources of international law, while upholding law-ascertainment without which there cannot be legal argumentation. ${ }^{147}$ It does not seem contested that as a result of the epistemological freedom to choose, in

\footnotetext{
${ }^{146}$ Meyer rightly interpreted Formalism and the Sources of International Law as seeking to preserve the possibility of communication; see Meyer, Towards a Communicative Theory of International Law, 1.

${ }^{147}$ In that sense, the rulelessness of sources advocated here share some of the ambitions of the 'culture of formalism' of Koskenniemi which also aims at preserving the horizon of universal argumentation. See M Koskenniemi, The Gentle Civilizer of Nations: The Rise and Fall of International Law 1870-1960 (CUP 2002) 502-509; M Koskenniemi, 'What is International Law For?', in M Evans (ed.), International Law (2nd ed., Oxford 2010) 57, 69-70. See also M Koskenniemi, 'Carl Schmitt, Hans Morgenthau and the Image of Law in International Relations’, in M Byers (ed.) The Role of Law in International Politics: Essays in International Relations and International Law (OUP 2000) 17, 32-3. Various interpretations of that concept have been offered in the literature. See among others, see E Jouannet, 'Présentation critique', in M Koskenniemi, La Politique du Droit International (Pedone 2007) 32-33. See also I de la Rasilla del Moral, 'Martti Koskenniemi and The Spirit of the Beehive in International Law' (2010) 10 Global Jurist; J von Bernstorff, 'Sisyphus was an international lawyer. On Martti Koskenniemi's "From Apologia to Utopia” and the place of law in international politics' (2006) 7 German Law Journal 1015, 1029-31; JA Beckett, " "Rebel Without a Cause”" Martti Koskenniemi and the Critical Legal Project' (2006) 7 German Law Review 1045; See also the book review of M Koskenniemi, The Gentle Civilizer of Nations by N Tsagourias (2003) 16 Leiden Journal of International Law 397, 398-9 or the remarks by d'Aspremont, Formalism and the Sources of International Law, 27-9.
} 
lieu of another, a given concept of law ${ }^{148}$ - or a given concept of sources - the discipline organised around international law is necessarily confrontational. Any international lawyer - even the nihilist - is an activist of his or her own understanding of law (and of its sources) and, hence, of a given way to make sense of the world. In that sense, confrontation is the fate of the international lawyer. ${ }^{149}$ Because it is inherent in legal scholarship, this confrontation should not be denied but should be lived, experienced and assumed: above all, it should be preserved. This is where the contrast between ruleness and rulelessness becomes manifest. Whilst the former seeks to conceal, behind a veil of stable and fixed rules, disagreement, conflict and dissent about the criteria of law-identification, the latter reveals the fluctuating and confrontational practice of recognition, and with it, the politics of definition. ${ }^{150}$ In short, defining the models of international lawidentification is where real power resides: ${ }^{151}$ it is time for international lawyers to come to terms with the deceitfulness of the idea of rules in the sources of international law and to face squarely the politics of lawascertainment in international law. This is the only way to preserve legal argumentation in the discipline.

\footnotetext{
${ }^{148}$ No concept of law is more valid than another and there is no meta-standpoint from which the validity of one concept and the invalidity of others can be affirmed. See M Koskenniemi, 'Letter to the Editors of the Symposium' (1999) 93 AJIL 351, 352; see also J d'Aspremont, 'International Lawyers Live!' (May 23, 2013), available at SSRN: http://ssrn.com/abstract=2271115 or http://dx.doi.org/10.2139/ssrn.2271115.

${ }_{149} \mathrm{~J}$ d'Aspremont, 'Wording in International Law' (2012) 25 Leiden Journal of International Law 575; Singh, International Law as a Technical Discipline.

${ }^{150}$ In that sense, it breaks away with the traditional formalist approach which rests on an 'excessive faith in the limiting power of equal rules and rule-systems and (h rests on an $f$ the - beneficial - role of law as a facilitator of the use of power for valuable purposes'. See M Koskenniemi, 'Methodology of International Law', Max Plank Encyclopedia of Public International Law, para. 22.

${ }^{151}$ Fish, Doing What Comes Naturally, 23-24.
} 